\title{
A data-driven analysis of the current debate on the linkages between performance and strategy studies
}

\author{
Nicola G. Castellano ${ }^{[1]^{*}}$, Katia Corsi[2], Monica \\ Bartolini[3], Francesca Bernini[4], Andrea \\ Cardoni[ ${ }^{[5]}$, Graziano Coller ${ }^{[6]}$, Vincenzo \\ Fasone $^{[7]}$ and Luca Fornaciari[ ${ }^{[8]}$
}

[1] Department of Economics and Law, University of Macerata. Italy. Email: nicola.castellano@unimc.it

[2] Department of Economics and Business Administration., University of Sassari. Italy. Email: kcorsi@uniss.it

[3] University of Bologna, Forlì Campus - Department of Management Studies.. Email: monica.bartolini4@unibo.it

[4] Department of Economics and Management. University of Pisa. Italy. Email: francesca.bernini@unipi.it

[5] Department of Economics, University of Perugia. Italy. Email: andrea.cardoni@unipg.it

[6] Department of Economics and Management, University of Trento. Italy. Email: graziano.coller@unitn.it

[7] Department of Economics and Law, Kore University of Enna. Italy. Email: vincenzo.fasone@gmail.com

[8] Department of Economics, University of Parma. Italy. Email: luca.fornaciari@unipr.it

* Corresponding author

\begin{abstract}
This paper focuses on how the relations between Performance Management and Measurement (PMM) and Strategy are considered by scholars. These relations are crucial in building a comprehensive body of knowledge of a complex and multifaceted phenomenon which attracts scholars pertaining to different management disciplines. The results obtained by adopting quantitative methodologies (descriptive statistics and text-mining analysis) on a sample of articles recently published in the most influential international "business, and management accounting" journals, contribute to extant literature by providing evidence that several connections exist between key-concepts which are usually considered an exclusive heritage of single management disciplines, such as strategy, organization, management control, and so forth. For that reason an integration of competences and methodologies is needed to support further research in the field. We also find evidence suggesting that the organizational perspective should be particularly considered when investigating the relations between strategy, management control systems and PMM.
\end{abstract}

Keywords: Performance Management, Performance Measurement, Strategy, Top-ranked Journals, Literature Review, Text Mining.

Reference to this paper should be made as follows: Castellano et al. (2018) 'A data-driven analysis of the current debate on the linkages between performance and strategy studies', Int. J. Business Performance Management. Vol. 19, Issue $1,105-129$.

Biographical notes: Nicola G. Castellano (PhD) is an associate professor of 
Author

management. His main fields of interest are: management control and performance measurement systems; business analytics; financial disclosure; innovation and performance.

Katia Corsi $(\mathrm{PhD})$ is Associated Professor of Management Control Systems. Her research interests are management control systems (in multinational as well as small companies), accounting information systems, financial disclosure and international accounting standards.

Monica Bartolini is an Associate Professor of management accounting. Her research interests are strategic cost management, management control systems, international financial reporting standards. She is lecturer in financial accounting and in management accounting in several master programs.

Francesca Bernini is a tenured researcher. She teaches Management and is responsible for the Corporate Finance area of the Master course in Auditing and Internal Control of the University of Pisa. She conducts her research in the fields of Business Valuation, Accounting and Family Business.

Andrea Cardoni $(\mathrm{PhD})$ is an Assistant Professor of management at Department of Economics at University of Perugia. He received the Ph.D. in Management Control at University of Florence and his current research interests include strategy, management control, performance analysis and business networking

Graziano Coller $(\mathrm{PhD})$ is assistant professor in Management Accounting and Control. His research is focused on the relationship between management control systems and strategy, on cost-based decision making and on accuracy of costing systems.

Vincenzo Fasone is an Assistant Professor. He has attended numerous national and international conferences and he has published books and several articles in scientific journals on the topics of performance measurement in the transportation and tourism industries researcher of management.

Luca Fornaciari $(\mathrm{PhD})$ is a researcher. He is author of publications concerning earnings management, value relevance, management accounting, the disclosure about corporate social responsibility of enterprises and, more generally, the processes related to disclosure of economic and financial information.

\section{Introduction}

Over the last decades a relevant body of literature has focused on the relationship between Management Control Systems (MCS) and strategy, revealing a pro-active (Hopwood, 1987; Dent, 1990) and interactive (Simons, 1994) role in MCS. Langfield Smith (1997) points out that the findings provided by the MCS-strategy streams of research remain ambiguous and sometimes contradictory and has inaugurated a new debate about the relationship between strategy, control and performance (Mundy, 2015). In particular, much attention has been paid to Performance Measurement Systems (PMSs) and their support to strategy implementation and (re)formulation, concluding that PMSs are particularly instrumental in this regard (Gimbert et al., 2010) and strategic PMSs still represent a key research stream and an extensive literature focuses on them. 


\section{A data-driven analysis of the current debate on the linkages between performance and strategy studies}

This special focus on the literature about the linkages between strategy and Performance Measurement and Management (PMM) has prompted the aim of this paper, i.e. an enrichment of the understanding of the current scientific debate, on the basis of the most influential international "business, management and accounting" journals. In particular, the paper explores the relevance of the literature on PMM-strategy linkages over the period 2013-2016 and the main research streams, as well as the research methods used. Through the discussion of previous issues, our study also provides academics with useful insights to orient their research strategies and consequent publications.

The data collected and analysed through both descriptive statistics and text-mining, highlight that the strategy and PMM linkages are strongly debated in papers focused on organization and human resource management issues, in which the qualitative methods (single and multiple case studies) prevail. In the future, the strategy-PMM linkage could be covered more fully by studies on business administration, integrating several competences and methodologies.

The remainder of this paper is structured as follows. Section 2 and 3 present the theoretical framework and the connected research questions developed accordingly. Section 4 describes the methodological aspects. Data analysis and results are reported in section 5 and, finally, section 6 concludes, highlighting the main results and limitations of the study, together with remarks for future research.

\section{Theoretical Background}

This paper deals with the studies on the linkages between MCS and strategy and, more precisely, between PMM and strategy.

Traditionally, the relationship between MCS and strategy has been viewed as a passive one, suggesting that the MCS is an outcome of an organizational strategy (Anthony, 1965). Organizations were viewed as goal-oriented entities and control was exerted to utilise resources effectively in pursuing those goals by influencing behaviour amidst environmental change. Control systems were largely concerned with feedback and feedforward processes and emphasis was given in minimizing the gap between actual results versus targets. Financial measures were largely employed as performance indicators, to set either the individual and the overall targets of the organization.

In the following years there have been calls for wider views of management control. Johnson and Kaplan (1987) described the limitations arising when management control systems rely exclusively on financial measures and argued for a focus on multidimension and operation-based measurement systems. Their considerations were the premises upon which the Balanced Scorecard (Kaplan and Norton, 1992) and other similar models aimed to accurately represent the linkages between strategy and operation initiatives were built.

In the same period Hopwood (1987) and Dent (1990), however, speculated that the MCS might play a pro-active role in influencing strategy. Hopwood (1987) suggested that management controls implemented for a particular reason could signal new potential and aid in the development of new directions. Even Simons (1994) showed how formal control systems, if used within interactive mechanisms, could overcome organizational inertia and drive managers behaviours also when emergent strategies were implemented. 
The system helped to communicate the strategic agenda and focus the managers attention on the uncertainties arising during the accomplishment of a new strategy.

On the contrary, Macintosh (1994) recognized that the association between MCS and strategy could be more than a simple mono-directional relationship. Moreover Langfield Smith (1997) pointed out that the findings provided within the streams of research related to MCS and strategy remained ambiguous and sometimes contradictory and inaugurated a new debate centred on a more complex relationship between three perspectives: strategy, control and performance (Mundy, 2015).

The first term of the relation suggests the existence of the traditional impact produced by strategy on MCS and performance: strategy $\Rightarrow \mathrm{MCS} \Rightarrow$ performance. Particularly, Bouwens and Abernethy (2000) examine the relation between strategy and MCS and propose a theoretical model to explain how and why this relation exists. They develop a theoretical argument concerning the interrelations among customization, interdependence and Management Accounting System (MAS), being particularly interested in assessing whether the relation between customization and MAS is a direct one or whether the relation operates via interdependence. The results indicated that customization affected MAS via interdependence, rather than directly.

The second approach is based on a counter-posed perspective (Henri, 2006; Marginson, 2002): strategy and performance are influenced by the MCS through the paradigm: MCS $\Rightarrow$ strategy $\Rightarrow$ performance. Specifically, Marginson (2002) discusses the effects that the design and the use of MCS produce on the development of new ideas and initiatives influencing strategic decisions, administrative controls and key performance indicators.

In a third approach the interacting effect: strategy $\Leftrightarrow$ MCS $\Rightarrow$ performance is discussed. Particularly Kober et al. (2007) suggest that there may be a two-way relationship between strategy and management control, while Gerdin et al. (2004) suggest that this interaction affects performance. In the same stream, Naranjo-Gil (2004) adopts a contingency framework to study how the relationship between prospector strategy and performance would be moderated by the sophisticated design of MCS. According to the previous argument he explores the contingency fit between MSC, strategy and performance, using a mediating and moderating model.

In the light of the significant evolution occurred on MCS and management accounting techniques (increase in internationalization practices, new cost management techniques, relevance of non-financial performance based on drivers for long-term survival), in the late $1980 \mathrm{~s}$ the reference in the academic literature to performance measurement perspective became increasingly visible and a deliberate shift in focus from MCS towards PMSs occurred (Demartini, 2014). Particularly Nanni et al. (1992, p. 9) specified that "the choice of the term performance measurement reflects an attempt to avoid more traditional accounting terms like control or performance evaluation. If management accounting and the environment in which it operates are currently facing a paradigm shift (Shank, 1989; Porter, 1990), it is best to use a term without strong connections to the old paradigm". Accordingly, some years later, Otley (2001, p. 249) identified the performance measurement and management as the "focus of many of the 'new' techniques of management accounting that have been developed over the past 20 years".

Some early definitions of performance measurement relied on performance indicators, specifying that grouping these indicators leads to a PMS. De Haas and Kleingeld (1999, p. 234) defined a PMS as a "set of performance indicators with procedures for periodic data gathering and the group of organizational actors they relate 
A data-driven analysis of the current debate on the linkages between performance and strategy studies

to, form the elements of a PM system. Simons (1995, p. 5; 2000, p. 4) tried to solve the conflict between performance measurement and control systems by asserting that both are "formal, information-based routines and procedures managers use to maintain or alter patterns in organizational activities".

A crucial contribution that extends the meaning and implications of performance measurement is represented by the Balanced Scorecard (BSC) approach in the mid1990s. Kaplan and Norton (1996, pp. 24-25) asserted that BSC is "a comprehensive framework that translates a company's vision and strategy into a coherent set of performance measures" specifying that BSC has not to be considered as a "controlling system". With the integrated and strategic approaches, the time has come for a link between a multi-dimensional perspective for measuring individual targets and performances and a strategic-oriented enabler for decision making and action (Demartini, 2014).

Since then a key role has been played by PMSs and strategic PMSs (SPMSs) as tools to enhance an effective strategy implementation. Consequently, most studies focus on the role of SPMSs regarding the translation of strategy into action, and strategy (re)formulation, concluding that SPMSs are particularly instrumental in this regard (Berry et al., 2009; Chapman 2005; Davila 2005; Gimbert et al., 2010; Ittner and Larcker 2005). Nowadays, SPMSs represent a key research stream and an extensive literature focuses on them, from a theoretical and a practical point of view. Gimbert et al. (2010) identify the following characteristics to define a SPMS: a) a combination of long-term and short-term horizons; b) an integration of financial and non-financial indicators; c) internal and external viewpoints; d) the presence of a forward-looking perspective; e) the definition of causal relationships among the different measures and perspectives included in the system.

A number of SPMS theoretical frameworks have been developed by scholars and practitioners (e.g. Lynch and Cross, 1991; Kaplan and Norton, 1992; Neely and Adams, 2000) and many studies deal with the diffusion and effectiveness of such frameworks or more generic set of non-financial measures (e.g. Fullerton and McWatters, 2002; Dossi and Patelli, 2010). Franco-Santos et al. (2012), through their evidence from a review of 76 empirical studies, suggest that PMSs significantly affect people's behaviour, organizational capabilities, and performance. They also found that those systems play a key role in strategy, communication, and management processes, coherently with Kaplan and Norton (2001) and Melnyk et al. (2004). More in detail, PMSs "facilitate the development, implementation, and review of business strategies by focusing people's decisions and actions on strategic goals and by encouraging a continuous dialogue about strategic endeavours" (Franco-Santos et al., 2012, p. 99).

In addition, Bisbe and Malagueño (2012) examine how SPMSs influence firm performance through the shaping of the strategic agendas. Using a combination of archival and survey data collected from 267 medium and large Spanish companies, the Authors find evidence of a positive association between SPMSs and performance, mediated by the comprehensiveness of the strategic decision arrays.

In sum, researchers agree that, to be effective, PMSs must comprise performance measures and targets with a high strategic alignment (Carneiro-Da-Cunha et al., 2016; de Harlez and Malagueño, 2016; Melnyk et al., 2014), and must be multidimensional and comprehensive (de Waal et al., 2009; Hansen and Schaltegger, 2016; Micheli et al., 2011). However, theoretical (Yadav at al., 2014) and empirical studies (Thaker, 2011) 
Author

exploring the linkages between PMM systems and strategic management theories state that still such systems are lacking in strategic thinking. Moreover, the evidence on SPMS models used in practice is still incomplete (Micheli and Manzoni, 2010) and -according to Chenhall (2005)- it is largely anecdotal, while Bisbe and Malagueño (2012) highlight that SPMS implementation can be merely virtual. These considerations justify the relevance of this subject in the current scientific debate.

\section{Research Questions}

Given the special focus of this study on the linkages between PMM and strategy and moving from the plethora of studies in the field reported in the previous section, a need to better understand how literature is evolving has arisen. Accordingly, this paper aims to review articles published on the most influential international "business, management and accounting" journals, and to offer an overview about the state of the research on the PMM-strategy linkages, highlighting both established issues and emerging research streams in the current debate. In doing so, we formulate the following core research questions:

$R Q 1$. How the scientific debate on PMM-strategy linkages is considered by the recent literature and particularly by the most influential international "business, management and accounting" journals over the period 2013-2016?

$R Q 2$. What are the main research streams in the current scientific debate on the PMM-strategy linkages?

Answering the above mentioned research questions, our paper contributes to literature by enriching the understanding of the current debate on the linkages between PMM and strategy. In particular, the main topics related to specific aspects of strategy generally investigated in the PMM studies' perspective (such as internalization, human relation management, corporate governance, etc.) are highlighted, through a qualitative analysis. Moreover, a text mining analysis is performed to identify the hidden regularities among the PMM-strategy linkages, detecting the emerging network of scientific topics connected to the PMM and strategy field of studies.

The current debate is also characterized by the adoption of an array of qualitative and quantitative research methods, such as case studies, surveys, quasi-experimental and experimental research; moreover, several literature reviews and theoretical papers have been published. Through the following additional research question, then, our paper also explores the following methodologic issue:

$R Q$ 3. What are the research methods used by researchers, in respect of the most relevant literature on the PMM-strategy linkages?

As additional outcome the paper contributes to inform academics about the key issues in the current debate on the PMM-strategy linkages, capturing the elements that characterize its evolution and emerging themes, as well as the most successful and valuable research methods and journals' focus. The results may be helpful for scholars to 
A data-driven analysis of the current debate on the linkages between performance and strategy studies

intercept publication opportunities and to orient their future research and publication efforts and strategies.

\section{Methodology}

The review process was based on the following strategy. For the identification of the relevant literature, papers were selected following the protocol suggested by Kitchenham (2004), in order to conduct a comprehensive research. The selection procedure, referring to the sample identification (see Table 1), was also guided by the review work in Grégoire et al. (2011).

Table 1 Sampling criteria

\begin{tabular}{|l|l|}
\hline \multicolumn{1}{|c|}{ Criteria } & \multicolumn{1}{c|}{ Rationales } \\
\hline $\begin{array}{l}\text { 1) Publication appeared on the most } \\
\text { influential international "business, } \\
\text { management and accounting" journals } \\
\text { indexed in the Italian "AIDEA Journal } \\
\text { Rating". }\end{array}$ & $\begin{array}{l}\text { This is done to narrow our search results } \\
\text { to articles published in journal that can } \\
\text { claim to produce a valuable impact on } \\
\text { academic research. }\end{array}$ \\
\hline $\begin{array}{l}\text { 2) Publication in a peer-reviewed } \\
\text { academic journal with a declared focus } \\
\text { on strategic management and } \\
\text { performance measurement. }\end{array}$ & $\begin{array}{l}\text { This is done to better focus the search on } \\
\text { the topic and aims of this specific work. }\end{array}$ \\
\hline $\begin{array}{l}\text { 3) Publication between 2013 and } \\
\text { January 2016. }\end{array}$ & $\begin{array}{l}\text { This is done to focus the research on the } \\
\text { most recent scientific debate. }\end{array}$ \\
\hline $\begin{array}{l}\text { 4) Use of the following combination of } \\
\text { keywords in the article's title, abstract } \\
\text { and/or keywords: "strateg*" and } \\
\text { "performance". }\end{array}$ & $\begin{array}{l}\text { This is done to reduce discretional } \\
\text { interpretative biases during the selection } \\
\text { of possible relevant works. }\end{array}$ \\
\hline $\begin{array}{l}\text { 5) Publication as a full-length journal } \\
\text { article or research note }\end{array}$ & $\begin{array}{l}\text { This is done to follow and share the } \\
\text { approach proposed by Busenitz et al. } \\
\text { (2013). }\end{array}$ \\
\hline
\end{tabular}

According to the previous sampling criteria, at first, the research was undertaken on the most influential international "business, management and accounting" journals listed in the "Journal Rating AIDEA 2015" (i.e. the ranking provided by the Italian Academy of Business Administration and Management). Second, we searched for journals with an explicit focus on strategic management and performance measurement, as declared in their aim and scope. We selected a total of 38 journals, listed in appendix 1.

We selected papers published between 2013 and January 2016 (including online first articles). Most of them were available in full-text, so the content could be easily searched through an examination of the keywords and abstracts. Well-known search engines have been used (e.g. ISI, Web of Science, Scopus, Google Scholar), yet, unpublished manuscripts and working papers have not been included. During the selection process, authors examined the articles (titles, keywords and abstract) by checking for the presence 
Author

of the following text-string: "strateg*" and "performance", in order to reduce subjective interpretation bias. To ensure that the papers incorporated the target concepts, we reviewed also the theoretical sections, consistent with Coviello and Jones (2004).

The categories used in this work emerged during the content analysis process and were also developed in line with researchers' reflections and questions (Esterberg, 2002). It should be noted that the review covers only articles published in journals, and does not extend to a systematic search of books or book chapters. Despite the discretionary choice, we recognize it as one that may have caused some influential contribution to be overlooked. Nevertheless, we consider the delimitation is arguable on the basis of the quality of review processes inherent in journals and on the basis of accessibility of the papers. Totally, we achieved to collect 220 publications.

\section{Data analysis}

\subsection{Descriptive statistics}

In order to answer our RQ 1, about the way PMM-strategy linkages are discussed in the literature over the period 2013-2016, we carried out some descriptive statistics on the sample of collected papers. As shown in Table 2, at least one article corresponding to our selection criteria was published in 33 of the 38 selected journals, with an average of 5.79 articles published per journal.

Table 2 Descriptive statistics on the total number of papers published

\begin{tabular}{cc|cr}
\hline \multicolumn{2}{c}{$\begin{array}{c}\text { Journals } \\
\text { Nr. of journals } \\
\text { with \# papers } \\
\text { published }\end{array}$} & \multicolumn{2}{c}{ Total } \\
\hline 0 & 5 & 0 & $0.0 \%$ \\
1 & 4 & 4 & $1.8 \%$ \\
2 & 4 & 8 & $3.6 \%$ \\
3 & 3 & 9 & $4.1 \%$ \\
4 & 4 & 16 & $7.3 \%$ \\
5 & 6 & 30 & $13.6 \%$ \\
6 & 3 & 18 & $8.2 \%$ \\
7 & 1 & 7 & $3.2 \%$ \\
9 & 2 & 18 & $8.2 \%$ \\
11 & 1 & 11 & $5.0 \%$ \\
14 & 1 & 14 & $6.4 \%$ \\
16 & 1 & 16 & $7.3 \%$ \\
18 & 1 & 18 & $8.2 \%$ \\
19 & 1 & 19 & $8.6 \%$ \\
32 & 1 & 32 & $14.5 \%$ \\
\hline
\end{tabular}


A data-driven analysis of the current debate on the linkages between performance and strategy studies

\begin{tabular}{lll}
\hline 38 & 220 & $100.0 \%$ \\
\hline
\end{tabular}

It's worth noting that approximately $50 \%$ of the scientific publications (110) included in the sample are concentrated on 6 journals and a number of articles ranging from 11 to 19 was published on 5 of them, while 32 articles (14.5\% of the whole sample) were published on the remaining one (Management Decisions).

Table 3 Authors per paper

\begin{tabular}{ccc}
\hline $\begin{array}{c}\# \\
\text { Authors }\end{array}$ & $\begin{array}{c}\text { Nr. of papers } \\
\text { with \# authors }\end{array}$ & $\%$ \\
\hline 1 & 31 & $14.1 \%$ \\
2 & 80 & $36.4 \%$ \\
3 & 79 & $35.9 \%$ \\
4 & 25 & $11.4 \%$ \\
$5+$ & 5 & $2.3 \%$ \\
\hline \multicolumn{3}{c}{}
\end{tabular}

As far as concerns the number of authors (see Table 3), the vast majority of papers $(72.3 \%)$ are written by two or three authors, with only $14.1 \%$ of single named papers and $13.7 \%$ of papers written by 4 authors or more.

Table 4 Papers per year

\begin{tabular}{ccc}
\hline Year & $\begin{array}{c}\text { Nr. of } \\
\text { papers }\end{array}$ & $\%$ \\
\hline 2013 & 81 & $36.8 \%$ \\
2014 & 58 & $26.4 \%$ \\
2015 & 71 & $32.3 \%$ \\
2016 & 10 & $4.5 \%$ \\
\hline & 220 & $100.0 \%$ \\
\hline
\end{tabular}

The number of papers published yearly from 2013 to 2015 are 81 (36.8\%), 58 $(26.4 \%)$ and $71(32.3 \%)$ respectively (see Table 4$)$. The sample also includes 10 papers published during January 2016, but the number is not significant, because it is obviously incomplete.

Table 5 Keywords corresponding with selection criteria

\begin{tabular}{ccc}
\hline Keywords & $\mathbf{N r}$ & \% \\
\hline Performance & 127 & $15.60 \%$ \\
Strateg* & 59 & $7.2 \%$
\end{tabular}




\begin{tabular}{ccc} 
Other & 629 & $77.20 \%$ \\
\hline & 815 & $100.00 \%$ \\
\hline
\end{tabular}

As far as concerns the research methodology, a quantitative approach is adopted in $58.2 \%$ of the papers; theoretical contributions account for $20.5 \%$; while case studies (single or multiple) are employed in $13.2 \%$ of the papers. Less frequently adopted methodologies are: experimental studies $(4.1 \%)$, literature reviews $(3.2 \%)$ and surveys $(2.7 \%)$. Further comments about the research methodologies are provided in section 5.5.

\subsection{Classification Criteria}

The selected papers have been grouped according to the general scientific topics characterizing the field of study and embracing the relations between strategies and PMM (see section 2), in order to provide a qualitative description about the most relevant research streams characterizing the current scientific debate on PMM and strategy. The categories represent the disciplines in management studies which are involved in the research about PMM and strategy. They have been identified by a common reading and discussion of the title, abstract and keywords of the papers selected.

Table 6 Selected topics in the strategy-PMM linkages’ perspective

\begin{tabular}{|c|c|}
\hline Topic & Description / Focus \\
\hline I & $\begin{array}{l}\text { Internationalization strategies, cross-border M\&A, exports, companies and } \\
\text { multinational groups, international collaboration and cultural integration. }\end{array}$ \\
\hline $\mathrm{BS}$ & $\begin{array}{l}\text { Business strategies issues: strategy's formulation, implementation and } \\
\text { valuation. }\end{array}$ \\
\hline HRM & $\begin{array}{l}\text { Human resources' management: social and cultural aspects of the } \\
\text { interaction between employees or performances related to labor } \\
\text { organization. }\end{array}$ \\
\hline IA & $\begin{array}{l}\text { Intangible assets: the role of the invisible key-resources and/or their } \\
\text { relations with strategies and the performances. }\end{array}$ \\
\hline ORG & Business organization studies related to strategy and/or performances. \\
\hline $\mathrm{N}$ & $\begin{array}{l}\text { Networks: strategies related to groups, corporate networks, alliances and } \\
\text { inter-company collaboration. }\end{array}$ \\
\hline $\mathrm{L}$ & Leaders: characteristics of the policy makers and leadership. \\
\hline $\mathrm{CG}$ & $\begin{array}{l}\text { Corporate Governance: links between performance, strategy and the } \\
\text { characteristics of the ownership structure and the board of directors. }\end{array}$ \\
\hline S & $\begin{array}{l}\text { Sustainability: strategies-PMMs linkages, in the perspective of } \\
\text { sustainability, ethics, environment and corporate social responsibility. }\end{array}$ \\
\hline MCS & Performances and Management Control System(s) issues. \\
\hline M & $\begin{array}{l}\text { Marketing: strategies-PMM linkages, observed with reference to the four } \\
\text { "Ps" of marketing mix perspective (Product, Price, Promotion, Place). }\end{array}$ \\
\hline $\mathrm{O}$ & Other: residual category \\
\hline
\end{tabular}


A data-driven analysis of the current debate on the linkages between performance and strategy studies

The classification of the articles within predetermined categories of topics is propaedeutic for the subsequent analyses. The classification procedure has been accomplished according to the categories listed in Table 6.

\subsection{Analysis concerning the distribution of the topics per year}

Our analysis begins by observing the distribution of the sampled articles, among the scientific topics (see Table 7).

Table 7 Analysis of scientific topics

\begin{tabular}{crr}
\hline Topic & $\begin{array}{c}\# \\
\text { Articles }\end{array}$ & \multicolumn{1}{c}{$\%$} \\
\hline I & 29 & 13.18 \\
BS & 26 & 11.82 \\
HRM & 15 & 6.82 \\
IA & 21 & 9.55 \\
ORG & 34 & 15.45 \\
N & 13 & 5.91 \\
L & 14 & 6.36 \\
CG & 9 & 4.09 \\
S & 18 & 8.18 \\
MCS & 27 & 12.27 \\
M & 8 & 3.64 \\
O & 6 & 2.73 \\
Tot & $\mathbf{2 2 0}$ & $\mathbf{1 0 0 . 0 0}$ \\
\hline
\end{tabular}

A relevant number of articles investigating the Strategy-PMM relation address organizational issues $(15.45 \%)$, whose number of publications is growing over time. In addition, in early 2016, we found four published papers belonging to the category "Business organizational studies", which represents in effect a wide research field, including several complex topics which could be further detailed in sub-categories, such as: ambidexterity organizations (Torres et al., 2015; Junni, 2013); innovation and learning orientation (Xu et al., 2015; Kyrgidou and Spyropoulou, 2013; Lichtenthaler, 2016); supply chain (Neumuller at al., 2016; Hendrix et al., 2015).

In terms of relevance, the most considered topics are: "internationalization" (13.18\%), "management control systems" (12.27\%) and "business strategy" (11.82\%). The latter topic show a downward trend over time: 13 and 7 papers were published in 2013 and 2015 respectively.

The less investigated topics relate to marketing (3.64\%) and corporate governance (4.09\%). However, CG issues show an upward trend over the three years, with articles focusing on the ownership concentration (King and Clarkson, 2015; Inoue et al., 2013; 
Boubakri et al., 2015); gender diversity (Post and Byron, 2015; Hoogendoom et al., 2013); family firms (Pindado and Requejo, 2015; Patel and Cooper, 2014).

Considering the RQ 2, this first analysis suggests that the selected journals mainly concern with organizational studies, which is a wide research field. Looking at the other topics, scholars are more interested in internationalization strategies and performance control systems. We may argue that the increased interest in these topics is due to, among other things, to the recent changes of the economic context. In particular, the economic and financial crisis (Tseng et al., 2013) may have led scholars to analyse the possibilities to react by adopting internationalization strategies, or paying attention to the improvement of performance (Zhou and $\mathrm{Wu}, 2014$ ) and to the implementation of control tools (Sage et al., 2014).

\subsection{A text mining approach to the literature review ${ }^{1}$}

To better explore RQ 2 and, in detail, the emerging network of scientific topics connected to the PMM and strategy field of studies, a text mining analysis has been performed.

The text mining techniques can help researchers to uncover hidden regularities lying among large sets of textual data which could be helpful for the description of the most relevant topics characterizing the field of studies of performance management/measurement and strategy.

The results could be particularly meaningful to understand and appraise how the several concepts, characterizing the research on PMM and Strategy, have developed within different disciplines and may be integrated into a unique body of knowledge.

In this section we will discuss the creation of a co-occurrences network (Fruchterman and Reingold, 1991), which allows to describe the relationships emerging between the most recurring keywords. The analysis has been performed with support of KHCoder software. The keywords recurring with higher $\%$ frequencies in the abstracts of the selected papers have been employed to create a co-occurrence network (see figure 1). Appendix 2 exhibits the complete list of the keywords with the related \% frequencies.

The network in figure 1 is composed by nodes connected through lines. The formers represent the keywords, whereas the lines put in evidence the logical connections between the keywords as they occur in the abstracts of the selected papers. Dashed lines represent weaker and less frequent co-occurrences between concepts. The length of lines and the proximity of nodes are created by the software arbitrarily and do not express the proximity of the conceptual association or the strength of the co-occurrence.

The "betweenness centrality" is used to assess the centrality of the concepts in the network (Freeman, 1977). The relevance of each node is measured by evaluating its presence in the connection paths between the other nodes.

In particular, the betweenness of a node $X$ equals to the number of paths of the minimal length for all the origin-destination node combinations that include node $X$, normalized according to the maximum number of possible combinations.

The elaboration process requires the following steps to be accomplished (Silchenko et al., 2015):

1. the identification of all the possible combinations of couples origin-destination node; 
A data-driven analysis of the current debate on the linkages between performance and strategy studies

2. the identification, for each combination in step 1 , of the minimal length connection path;

3. the assessment of the number of connection paths that involve a specific node (with exclusion of all the connection paths where origin and destination are represented by the same node);

4. the calculation of the total number of connected node couples in step 3;

5. the normalization of the values obtained in step 3 and the normalization of the maximum measure obtained in step 4 .

Figure 1Co-Occurrences Network

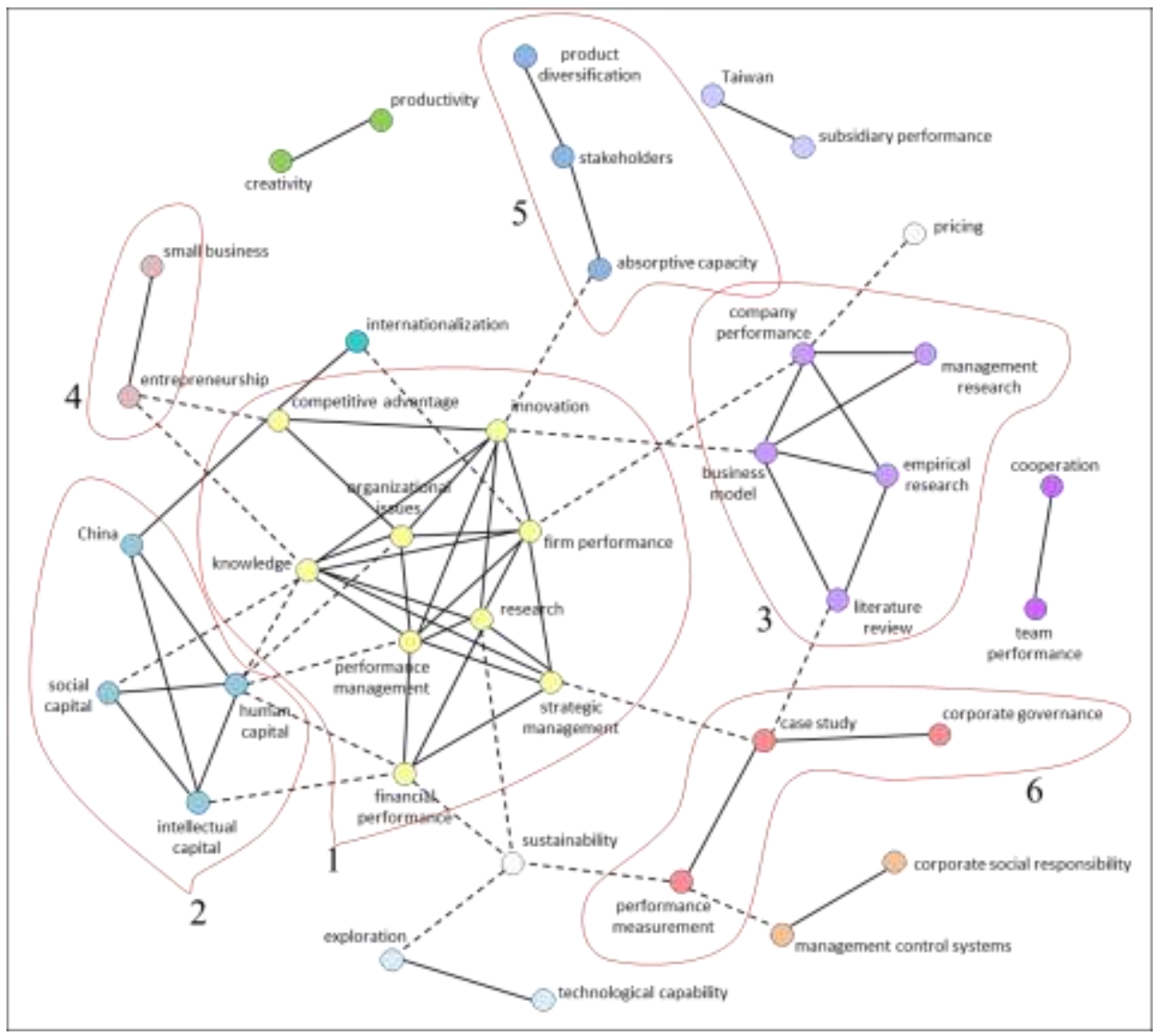

The groups of connected concepts in figure 1 provide additional insights about the several streams of research which are considered for publication on top-ranked management accounting and strategy journals. In this case the concepts in the map are different from the topics used in the previous section, since they are identified by using a discovery approach on the data. 


\section{Author}

Group 1 is the most dense. The concepts "firm performance", "performance management", and "financial performance" are directly connected to "strategic management", which show a logic proximity. Steigenberger (2014) and Luoma (2015) explicitly refer to the relations between strategic management and performance measurement. The former adopts the Resource Based Theory trying to fill a theoretical gap between value creation and firm financial performance, while the latter proposes a research methodology which could help researchers to find new and interesting insights about the strategy-performance relation. The results obtained evidence in particular the potential of hybrid strategies in supporting superior performances. Furthermore, Melnyk et al. (2014) investigate the concept of "strategic fit", that is the alignment between strategic purposes and performance measures which can inhibit the ability to sustain competition.

Diversely, the connection between the same performance concepts and more specific strategic terms, such as "competitive advantage" and "innovation", is an indirect one and is mediated by interdisciplinary subjects, such as "knowledge" and "organizational issues". These concepts refer to a really fertile strand of research. Studies on knowledge investigate the impacts on firms performance of a wide array of factors (Victer, 2014) such as entrepreneurial and learning orientation (Lonial and Carter, 2015), relational capabilities (Khalid and Bhatti, 2015; Zacca et al., 2015) or organizational ambidexterity (Junni et al. 2013) just to name a few.

The innovation-performance relation is also a field of remarkable interest for scholars. Chenhall and Moers (2015) describe how the design of management control systems have evolved over the years in order to include innovation, while Expósito-Langa et al. (2015) investigate the determinants of firm's innovation performance. It's worth noting that in several studies, innovation and organizational issues are considered as interrelated concepts affecting performance (Alegre et al., 2013; Choi et al., 2013; Ederer and Manso, 2013).

The terms "competitive advantage" and "innovation", in turn, show connections to the groups of concepts 2, 3, 4 and 5. In particular, the studies on competitive advantage, from the one hand pertain to a stream of research which seem to deal in particular with "internationalization" and "China".

Within performance management studies, China is considered as a sort of laboratory in which to investigate how different resources and strategies - internationalization in particular - may explain consequences on performance. The literature is considerably wide since China attracts the interest of scholars both as an emerging country in which internationalization strategies are often undertaken (Cooper and Ezzamel, 2013; Chen et al., 2014; Wua et al., 2016; Xiao et al. 2015; Zhou, et al. 2013), or as a reference country for research concerning specific industries, such as automotive (Xie and Li, 2015), or electronics (Shan and Jolly, 2013). China is also considered in a relevant number of studies in which the mediating effect of the knowledge framework on internationalization and performance is investigated (Li and Lee, 2015; Wang et al., 2014; Wei et al., 2013).

The term "competitive advantage" also shows a weaker connection with "entrepreneurship" and "small businesses" (group 4). Small-medium companies and family firms, are often considered as a peculiar environment in which the effectiveness of innovation strategies may be mediated by entrepreneurial and managerial capabilities (De Massis et al., 2015; Parnell et al. 2015; Whittaker et al., 2016).

Competitive advantage and innovation are also connected to groups 3 and 5 . Researches in group 5 focus on specific types of innovation and particularly on "product 
A data-driven analysis of the current debate on the linkages between performance and strategy studies

diversification" (Su and Tsang, 2015; Osorio et al., 2015; Hautz et al., 2013) and "absorptive capacity" (Zhang et al., 2015; Xie et al., 2015; Wu et al., 2016) which are expected to produce a direct or a moderating effect on performance, considered under a financial or innovation perspective.

Group 3 is also particularly meaningful to understand the connections between performance measurement/management and strategy. In this case the node "innovation" is weakly connected to "business models" which, in turn, is connected to company performance. The methodologies rather than the specific subjects seem to be connected to the nodes, showing that literature review (Lambert and Davidson, 2013) and empirical research (Morris et al. 2013; Lichtenthaler, 2016; Ghezzi, 2013) are frequently employed within the studies on business models.

Finally, the researches on "performance measurement" are connected to "strategic management" in a path conditioned by case studies and corporate governance (MacKay and Chia, 2013; Xiao et al. 2013). Weaker connections with corporate social responsibility (Mundy, 2013) and sustainability (Eccles and Serafeim, 2013) are also identified.

\subsection{Analysis concerning the relation between topics and research methods}

Our RQ 3 aims at exploring the research methods used by researchers, in respect of the most relevant literature on the PMM-strategy linkages. Our analysis is based on the classification described in section 4.2, which shows that the quantitative methods are the most commonly used, with a prevalence of statistical regressions (see table 8).

Table 8 Combined analysis of scientific methods and research topics

\begin{tabular}{cccccccc}
\hline & \multicolumn{7}{c}{ Research methods } \\
Topics & SCS & MCS & QUA & THE & EXP & LIT & SUR \\
\hline I & $10 \%$ & $0 \%$ & $62 \%$ & $28 \%$ & $0 \%$ & $0 \%$ & $0 \%$ \\
BS & $12 \%$ & $4 \%$ & $69 \%$ & $4 \%$ & $4 \%$ & $4 \%$ & $4 \%$ \\
HRM & $0 \%$ & $7 \%$ & $67 \%$ & $20 \%$ & $7 \%$ & $0 \%$ & $0 \%$ \\
IA & $0 \%$ & $5 \%$ & $76 \%$ & $19 \%$ & $0 \%$ & $0 \%$ & $0 \%$ \\
ORG & $21 \%$ & $0 \%$ & $53 \%$ & $12 \%$ & $6 \%$ & $6 \%$ & $3 \%$ \\
N & $0 \%$ & $15 \%$ & $77 \%$ & $0 \%$ & $0 \%$ & $0 \%$ & $8 \%$ \\
L & $0 \%$ & $0 \%$ & $64 \%$ & $14 \%$ & $14 \%$ & $7 \%$ & $0 \%$ \\
CG & $0 \%$ & $0 \%$ & $78 \%$ & $0 \%$ & $11 \%$ & $11 \%$ & $0 \%$ \\
S & $11 \%$ & $17 \%$ & $39 \%$ & $22 \%$ & $0 \%$ & $6 \%$ & $6 \%$ \\
MCS & $15 \%$ & $4 \%$ & $33 \%$ & $37 \%$ & $4 \%$ & $4 \%$ & $4 \%$ \\
M & $13 \%$ & $0 \%$ & $50 \%$ & $38 \%$ & $0 \%$ & $0 \%$ & $0 \%$ \\
O & $0 \%$ & $0 \%$ & $33 \%$ & $33 \%$ & $17 \%$ & $0 \%$ & $17 \%$ \\
$\#$ & 20 & 9 & 128 & 41 & 9 & 7 & 6 \\
\hline
\end{tabular}


Author

\begin{tabular}{llllllll}
$\%$ & $9.1 \%$ & $4.1 \%$ & $58.2 \%$ & $20.5 \%$ & $4.1 \%$ & $3.2 \%$ & $2.7 \%$ \\
\hline
\end{tabular}

SCS = Single Case Study; MCS = Multiple Case Study; QUA = Quantitative; THE $=$ Theoretical; EXP = Experimental; LIT = Literature Review; SUR = Survey

Theoretical proposals seem to be relevant only within the MCS studies and generally refer to performance measurement systems frameworks. Qualitative methods (single and multiple case studies) are totally unemployed in the topics of "Corporate Governance" and Leadership (L), while they are most common in the contributions focused on Organization (ORG), and Sustainability (S).

\subsection{Analysis concerning the topics covered by the selected journals}

Table 9 shows how the topics connected to PMM and strategy are considered for publication. The journals listed in table 9 are those with a publication frequency higher than $20 \%$ on one or more topic. In addition, we intend to highlight whether particular issues are exclusively considered by specific journals. For instance $31 \%$ of articles on BS (Business Strategy) are published on the journal Management Decision. In the same journal, articles also dealing with Intangible Assets (IA) and Network Strategies (N) are remarkably considered.

Table 9 Journals with higher publication frequency and scientific topics

\begin{tabular}{|c|c|c|c|c|c|c|c|c|c|c|c|c|}
\hline Journal & $\mathrm{I}$ & $\mathrm{BS}$ & HRM & IA & ORG & $\mathrm{N}$ & $\mathrm{L}$ & $\mathrm{CG}$ & $S$ & MCS & $M$ & $\mathrm{O}$ \\
\hline $\begin{array}{l}\text { Academy of } \\
\text { Management } \\
\text { Journal }\end{array}$ & $7 \%$ & $19 \%$ & $0 \%$ & $5 \%$ & $3 \%$ & $8 \%$ & $14 \%$ & $33 \%$ & $0 \%$ & $4 \%$ & $0 \%$ & $0 \%$ \\
\hline $\begin{array}{l}\text { Accounting, } \\
\text { Organizations and } \\
\text { Society }\end{array}$ & $3 \%$ & $8 \%$ & $0 \%$ & $0 \%$ & $6 \%$ & $0 \%$ & $0 \%$ & $11 \%$ & $22 \%$ & $15 \%$ & $0 \%$ & $0 \%$ \\
\hline $\begin{array}{l}\text { Human Resource } \\
\text { Management }\end{array}$ & $0 \%$ & $0 \%$ & $27 \%$ & $0 \%$ & $0 \%$ & $0 \%$ & $7 \%$ & $0 \%$ & $0 \%$ & $0 \%$ & $0 \%$ & $0 \%$ \\
\hline $\begin{array}{l}\text { Human Resource } \\
\text { Management } \\
\text { Review }\end{array}$ & $0 \%$ & $0 \%$ & $20 \%$ & $5 \%$ & $0 \%$ & $0 \%$ & $0 \%$ & $0 \%$ & $0 \%$ & $0 \%$ & $0 \%$ & $0 \%$ \\
\hline $\begin{array}{l}\text { Journal of Small } \\
\text { Business } \\
\text { Management }\end{array}$ & $0 \%$ & $4 \%$ & $0 \%$ & $10 \%$ & $0 \%$ & $23 \%$ & $14 \%$ & $0 \%$ & $0 \%$ & $0 \%$ & $0 \%$ & $17 \%$ \\
\hline $\begin{array}{l}\text { Journal of World } \\
\text { Business }\end{array}$ & $45 \%$ & $0 \%$ & $0 \%$ & $5 \%$ & $0 \%$ & $0 \%$ & $14 \%$ & $0 \%$ & $11 \%$ & $0 \%$ & $0 \%$ & $17 \%$ \\
\hline $\begin{array}{l}\text { Management } \\
\text { Accounting } \\
\text { Research }\end{array}$ & $0 \%$ & $0 \%$ & $7 \%$ & $0 \%$ & $9 \%$ & $0 \%$ & $0 \%$ & $0 \%$ & $22 \%$ & $33 \%$ & $13 \%$ & $0 \%$ \\
\hline $\begin{array}{l}\text { Management } \\
\text { Decision }\end{array}$ & $3 \%$ & $31 \%$ & $0 \%$ & $33 \%$ & $18 \%$ & $23 \%$ & $0 \%$ & $11 \%$ & $17 \%$ & $7 \%$ & $13 \%$ & $0 \%$ \\
\hline $\begin{array}{l}\text { Management } \\
\text { Science }\end{array}$ & $0 \%$ & $4 \%$ & $7 \%$ & $5 \%$ & $3 \%$ & $0 \%$ & $7 \%$ & $11 \%$ & $6 \%$ & $4 \%$ & $13 \%$ & $33 \%$ \\
\hline $\begin{array}{l}\text { Sloan Management } \\
\text { Review MIT }\end{array}$ & $0 \%$ & $0 \%$ & $0 \%$ & $0 \%$ & $0 \%$ & $8 \%$ & $0 \%$ & $0 \%$ & $0 \%$ & $4 \%$ & $38 \%$ & $0 \%$ \\
\hline
\end{tabular}


A data-driven analysis of the current debate on the linkages between performance and strategy studies

Table 9 shows that almost half (45\%) of the 29 papers on internationalization are published on the Journal of World Business, which is one of the most important journals in the field of international business. The 34 and contributions concerning Organization and Leadership respectively, however, are fairly distributed in the examined journals: in fact all the publication frequencies are lower than $20 \%$.

There are also journals in which at least one-third of the papers on the same topic is published, such as Academy of Management Journal (Corporate Governance) and Management Accounting Research (Management Control System). The contributions dealing with Marketing are concentrated mainly in the "Sloan Management Review" ( $38 \%$ of these papers).

The data highlight that the relationships between PMM and strategy (variously understood) represent an extremely inter-disciplinary theme. This is confirmed by the fact that, generally, the journals considered rely on several topics, with the exception of "Human Resource Management" and "Human Resource Management Review" which, seem to give exclusive attention to human resources strategies, as easily arguable by the journal title.

\section{Conclusions}

The paper intends to explore how the relations between PMM and strategy are considered by the most recent literature. Our intent is to provide academics with useful insights to orient their research strategies and consequent publications, pointing out both the main research streams in the current scientific debate, as well as the research methodologies, and how they are considered for publication on the top-ranked management accounting journals.

Accordingly, this work emphasizes how three different approaches to the analysis of the relationship between strategy $\Rightarrow \mathrm{MCS} \Rightarrow$ performance exist. In the first, a theoretical argument concerning the inter-relations among customization, interdependence and Management Accounting System (MAS) is provided, in the second a counter-posed perspective is suggested, in the third the interacting effect is discussed.

In addition it is clear that SPMSs represent a key research stream and various theoretical frameworks have been developed by scholars and practitioners. However, a lack in strategic thinking in the analysis of the linkages between PMM systems and strategic management theories can justify the relevance of this subject in the current scientific debate.

We performed descriptive statistics and a text mining analysis on a sample of articles published between 2013 and January 2016 in order to find answer to three research questions.

With regard to RQ 1 and RQ 2 our analysis shows that the relation Strategy-PMM is investigated under several perspectives. In particular Business organization (15.45\%), whose studies focus on organizational structure, operational processes, learning process. Instead, the papers focused on Business administration mainly regard Internalization (13.18\%), MCS (12.27\%) and Business strategy (11.82\%). The topics selected are considered for publication particularly on 6 out of the 38 selected journals. In general, the journals concentrate on one or few of the scientific topics simultaneously, showing that publications on the theme are basically mono-discipline. 
Author

Conversely, the results provided by the text mining analysis show that a wide and multi-faceted connection of concepts pertaining to several management and organizational disciplines exists in this field of study. In particular, the concepts of "firm performance", "performance management", and "financial performance" are connected to "strategic management" consistent with the results of Steigenberger (2014) and Luoma (2015). In addition, the results provided by the text mining analysis show the connections between performance measurement/management and strategy. In particular the key concept "innovation" is weakly connected to "business models", showing that literature review and empirical research are used for the research on business models. "Performance measurement" are also connected to "strategic management" and weaker connections are also identified with corporate social responsibility and sustainability.

The evidences collected suggest that the relation defined by Langfield Smith (1997) between Strategy, Management Control Systems and Performance could include Organisation as an explicit additional perspective:

$$
\text { Strategy - MCS - Organisation - Performance }
$$

Further research is then needed to understand how the four perspectives impact one on each other, or how they interact.

Concerning the research methods (RQ 3), generally the authors tend to adopt quantitative methods. Single and multiple case studies, although not prevalent, are particularly adopted in studies dealing with Organization and Sustainability, Environment, CRS and Ethics.

The research is essentially empirical, theoretical proposals are relevant only for what concerns the topic of Management Control Systems.

As limitations for the study, we have to consider that the data-set analysed is rather small. This produces biases on the concepts considered in the analysis as relevant or recurring. Furthermore a lack of data is documented since some of the selected journals do not require keywords in their publication format.

To conclude, we believe that the results obtained show that further research is needed, particularly, to develop literature on those connections which exist between topics that actually involve scholars who pertain to single management disciplines.

Particularly arguable is the integration between organizational studies, strategic management and performance measurement. The integration should also involve the research methodologies, since the analysis of case studies prevail within organizational studies, while quantitative methods seem to be widespread in the remaining management disciplines.

\section{References}

Adler, R.W. (2011) 'Performance management and organizational strategy: How to design systems that meet the needs of confrontation strategy firms', British Accounting Review, Vol. 43 No. 4, pp. 251-263.

Alegre, J. and Chiva, R. (2013) 'Linking Entrepreneurial Orientation and Firm Performance: The Role of Organizational Learning Capability and Innovation Performance', Journal of Small Business Management, Vol. 51, No. 4, pp. 491-507. 
A data-driven analysis of the current debate on the linkages between

performance and strategy studies

Anthony, R.N. (1965). 'Planning and Control Systems: A framework for Analysis', Boston, MA: Harvard Business School Press.

Arjaliès, D.L. and Mundy, J. (2013) 'The use of management control systems to manage CSR strategy: A levers of control perspective', Management Accounting Research, Vol. 24, No. 4, pp. 284-300.

Benito-Osorio, D., Colino, A. and Zúñiga-Vicente, J.A. (2015) 'The link between product diversification and performance among Spanish manufacturing firms: Analyzing the role of firm size', Canadian Journal Of Administrative Sciences, Vol. 32, No. 1, pp. $58-72$.

Berry, A.J., Coad, A.F., Harris, E.P. and Otley, D.T. (2009) 'Stringer C., 'Emerging Themes in Management Control: A Review of Recent Literature', The British Accounting Review, Vol. 41, pp. 2-20.

Bisbe, J. and Malagueño, R. (2012) 'Using strategic performance measurement systems for strategy formulation: Does it work in dynamic environments?', Management Accounting Research, Vol. 23, No. 4, pp. 296-311.

Boubakri N., Guedhami O., Kwok C.Y. and Saffar W. (2015), 'National culture and privatization: The relationship between collectivism and residual state ownership', Journal of International Business Studies, Vol. 47, No. 2, pp. 170-190.

Bouwens, J. and Abernethy, M.A. (2000). 'The consequences of customization on management accounting system design', Accounting, Organization and Society, vol.25, pp. 221-259.

Busenitz, L.W. and Barney, J.B. (1997). 'Differences between entrepreneurs and managers in large organizations: biases and heuristics in strategic decision-making', Journal of Business Venturing, vol. 12, pp. 9-30.

Carneiro-Da-Cunha, J.A., Hourneaux, F.,Jr. and Corrêa, H.L. (2016) 'Evolution and chronology of the organizational performance measurement field', International Journal of Business Performance Management, Vol. 17 No. 2, pp. 223-240.

Chapman, C.S. (2005), 'Controlling strategy'. In Chapman, C.S. (Ed), Controlling strategy: Management, accounting, and performance measurement, Oxford University Press, New York, pp. 1-9.

Chen, Y., Jiang, Y., Wang, C. and Hsu, W.C. (2014) 'How do resources and diversification strategy explain the performance consequences of internationalization?', Management Decision, Vol. 52, No. 5, pp. 897-915.

Chenhall, R.H. (2005) 'Integrative strategic performance measurement systems, strategic alignment of manufacturing, learning and strategic outcomes: an exploratory study', Accounting, Organizations and Society, Vol. 30 No. 5, pp. 395-422.

Chenhall, R.H. and Moers, F. (2015) 'The role of innovation in the evolution of management accounting and its integration into management control', Accounting, Organizations and Society, Vol. 47, pp. 1-13.

Choi, B.K., Moon, H.K. and Ko, W. (2013) 'An organization's ethical climate, innovation, and performance: Effects of support for innovation and performance evaluation', Management Decision, Vol. 51, No. 6, pp. 1250-1275.

Cooper, D.J. and Ezzamel, M. (2013) 'Globalization discourses and performance measurement systems in a multinational firm', Accounting, Organizations and Society, Vol. 38, No. 4 pp. 288-313.

Coviello, N. and Jones, M. (2004) 'Methodological issues in international entrepreneurship research', Journal of Business Venturing, Vol. 19, pp. 485-508. 
Author

Davila, T. (2005), 'The promise of management control systems for innovation and strategic change'. In Chapman, C. S. (Ed), 'Controlling strategy: Management, accounting, and performance measurement', Oxford University Press, New York, pp. 37-61.

De Haas, M. and Kleingeld, A. (1999) 'Multilevel design of performance measurement systems: enhancing strategic dialogue throughout the organization', Management Accounting Research, Vol. 10, pp. 233-261.

De Harlez and Malagueño, R. (2016) 'Examining the joint effects of strategic priorities, use of management control systems, and personal background on hospital performance', Management Accounting Research, Vol. 30, pp. 2-17.

De Massis, A., Di Minin, A. and Frattini, F. (2015) 'Family-Driven Innovation: resolving the paradox in family firms', California Management Review, Vol. 58, No. 1, pp. 519.

De Waal, A., Kourtit, K. and Nijkamp, P. (2009) 'The relationship between the level of completeness of a strategic performance management system and perceived advantages and disadvantages', International Journal of Operations \& Production Management, Vol. 29, No. 12, pp. 1242-1265.

Demartini, C. (2014) 'Performance Management Systems. Design, Diagnosis and Use', Springer, New York.

Dent, J.F. (1990). 'Strategy, organization and control: some possibilities for accounting research', Accounting, Organization and Society, vol. 15, pp. 3-24.

Dossi, A. and Patelli, L. (2010), 'You Learn From What You Measure: Financial and Non-financial Performance Measures in Multinational Companies', Long Range Planning, Vol. 43, No. 4, pp. 498-526.

Eccles, R.G. and Serafeim, G., (2013) 'The Performance Frontier', Harvard Business Review, Vol. 91, No. 5, pp. 50-60.

Ederer, F. and Manso, G, (2013) 'Is Pay for Performance Detrimental to Innovation?', Management Science, Vol. 59, No. 7, pp. 1496-1513.

Esterberg, K. G. (2002) 'Qualitative methods in social research'. Boston: McGraw-Hill.

Expósito-Langa, M., Molina-Morales, F.X. and Tomás-Miquel, J.V. (2015) 'How shared vision moderates the effects of absorptive capacity and networking on clustered firms' innovation', Scandinavian Journal of Management, Vol. 31, No. 3, pp. 293-302.

Franco-Santos, M., Lucianetti, L. and Bourne, M. (2012) 'Contemporary performance measurement systems: A review of their consequences and a framework for research', Management Accounting Research, Vol. 23, No. 2, pp. 79-119.

Freeman, L.C. (1977) 'A set of measures of centrality based on betweenness' Sociometry, Vol. 40, No. 1, pp. 35-41.

Fruchterman, T.M.J. and Reingold, E.M. (1991) 'Graph drawing by force-directed placement' Software-Practice and Experience, Vol. 21, No. 1 pp. 1129-1164.

Fullerton, R.R. and McWatters, C.S. (2002) 'The role of performance measures and incentive systems in relation to the degree of JIT implementation', Accounting, Organizations and Society, Vol. 27 No. 8, pp. 711-735.

Gerdin, J. and Greve, J. (2004) 'Forms of contingency fit in management accounting research: a critical review', Accounting, Organization and Society, Vol. 29, pp. 303326.

Ghezzi, A., (2013) 'Revisiting business strategy under discontinuity' Management Decision, Vol. 51, No. 7, pp. 1326-1358. 
A data-driven analysis of the current debate on the linkages between

performance and strategy studies

Gimbert, X., Bisbe, J. and Mendoza, X. (2010). 'The role of performance measurement systems in strategy formulation processes', Long Range Planning, Vol. 43, No. 4, pp. 477-497.

Grégoire, D., Corbett, A. and McMullen, J. (2011) 'The cognitive perspective in entrepreneurship: an agenda for future research', Journal of Management Studies, Vol. 48, pp.1443-1477.

Hansen, E.G. and Schaltegger, S. (2016) 'The Sustainability Balanced Scorecard: A Systematic Review of Architectures', Journal of Business Ethics, Vol. 133 No. 2, pp. 193-221.

Hautz, J., Mayer, M.C.J. and Stadler, C., (2013) 'Ownership identity and concentration: a study of their joint impact on corporate diversification', British Journal of Management, Vol. 24, No. 1, pp. 102-126.

Hendricks K. B., Hora M., and Singhal V.R. (2015) 'An Empirical Investigation on the Appointments of Supply Chain and Operations Management Executives', Management Science, Vol. 61 No. 7, pp.1162-1183.

Henri, J.G. (2006). 'Management control systems and strategy: A resource based perspective', Accounting, Organization and Society, vol. 31, pp.529-558.

Hoogendoom S, Oosterbeek H. and Van Praag M. (2013) 'The Impact of Gender Diversity on the Performance of Business Teams: Evidence from a Field Experiment', Management Science, Vol. 59, No. 7, pp. 1514-1528.

Hopwood, A.G. (1987). 'The archaeology of accounting systems', Accounting, Organization and Society, vol. 12, pp. 207-234.

Inoue C., Lazzarini S. and Musacchio A. (2013), 'Leviathan as a Minority Shareholder: Firm-Level Implications of State Equity Purchases', Academy of Management Journal, Vol. 56, No. 6, pp. 1775-1801.

Ittner, C.D. and Larcker, D. F. (2005) 'Moving from strategic measurement to strategic data analysis', In Chapman C. S. (Ed), 'Controlling strategy: Management, accounting, and performance measurement', Oxford University Press, New York, pp. 86-105.

Johnson, H.T. and Kaplan, R.S., (1987) 'The rise and Fall of Management Accounting', Boston. MA, Harvard Business School Press.

Junni, P., Sarala M.R., Taras, V. and Tarba, S.Y. (2013) 'Organizational ambidexterity and performance: A meta-analysis', Academy of Management Perspectives, 27(4), 299-312.

Kaplan, R.S. and Norton, D.P. (1992) 'The balanced scorecard - measures that drive performance', Harvard Business Review, Vol. 83, No. 7, pp. 71-79.

Kaplan, R.S. and Norton, D.P. (2001) 'The strategy-focused organizations: How Balanced Scorecard companies thrive in the new business environment', Harvard Business School Press, Boston, MA.

Khalid, S. and Bhatti, K. (2015) 'Entrepreneurial competence in managing partnerships and partnership knowledge exchange: Impact on performance differences in export expansion stages', Journal of World Business, Vol. 50, No. 3, pp. 598-608.

King R., Clarkson P. (2015), 'Management control system design, ownership, and performance in professional service organisations', Accounting, Organizations and Society, Vol. 45, pp. 24-39. 
Author

Kitchenham, B. (2004) 'Procedures for Undertaking Systematic Reviews', Joint Technical Report, Keele University (TR/SE-0401) and National ICT Australia, Ltd (0400011T.1).

Kober, R., Ng J. and Paul, B.J. (2007) 'The interrelationship between management control, mechanism and strategy', Management Accounting Research, vol. 18, pp. 425-452.

Kyrgidou 1. P. and Spyropoulou S. (2013) 'Drivers and Performance Outcomes of Innovativeness: An Empirical Study', British Journal of Management, Vol. 24, No. 3, pp. 281-298.

Lambert, S.C., and Davidson, R.A. (2013) 'Applications of the business model in studies of enterprise success, innovation and classification: An analysis of empirical research from 1996 to 2010'. European Management Journal, Vol. 31, No. 6, pp. 668-681.

Langfield Smith, K. (1997). 'Management Control System and Strategy: a critical review', Accounting, Organization and Society, vol. 22, pp. 207-232.

Li, J. and Lee, R.P. (2015) 'Can knowledge transfer within MNCs hurt subsidiary performance? The role of subsidiary entrepreneurial culture and capabilities', Journal of World Business, Vol. 50, No. 4, pp. 663-673.

Lichtenthaler U. (2016), 'Toward an innovation-based perspective on company performance', Management Decision, Vol. 54, No. 1, pp. 66-87.

Lonial, S.C. and Carter, R.E. (2015) 'The Impact of Organizational Orientations on Medium and Small Firm Performance: A Resource-Based Perspective', Journal of Small Business Management, Vol. 53, No. 1, pp. 94-113.

Luoma, M.A. (2015) 'Revisiting the strategy-performance linkage: An application of an empirically derived typology of strategy content areas', Management Decision, Vol. 53, No. 5, pp. 1083-1106.

Lynch, R.L. and Cross, K.F. (1991) 'Measure Up! Yardstick For Continuous Improvement', Blackwell, Cambridge, MA.

Macintosh, N.B. (1984) 'Management Accounting and Control Systems: An organizational and Behavioral Approach', Chichester, John Wiley and Sons.

MacKay, R.B., and Chia, R. (2013) 'Choice, chance, and unintended consequences in strategic change: a process understanding of the rise and fall of Northco Automotive'. Academy of Management Journal, Vol. 56, No. 1, pp. 208-230.

Marginson, D.E.W. (2002) 'Management control systems and their effects on strategy formation at middle-management levels: evidence from a U.K. organization', Strategic Management Journal, Vol. 23, pp. 1019-1031.

Melnyk, S.A., Bititci, U., Platts, K., Tobias J. and Andersen, B. (2014) 'Is performance measurement and management fit for the future?', Management Accounting Research, Vol. 25 No. 2, pp. 173-186.

Melnyk, S.A., Stewart, D.M. and Swink, M. (2004) 'Metrics and performance measurement in operations management: dealing with the metrics maze', Journal of Operations Management, Vol. 22, No. 3, pp. 209-217.

Micheli, P. and Manzoni J.F. (2010) 'Strategic Performance Measurement: Benefits, Limitations and Paradoxes', Long Range Planning, Vol. 43, No. 4, pp. 465-476.

Micheli, P., Mura, M. and Agliati, M. (2011) 'Exploring the roles of performance measurement systems in strategy implementation: The case of a highly diversified group of firms', International Journal of Operations and Production Management, Vol. 31 No. 10, pp. 1115-1139. 
A data-driven analysis of the current debate on the linkages between

performance and strategy studies

Morris, M.H., Shirokova, G. and Shatalov, A. (2013) 'The business model and firm performance: The case of Russian food service ventures', Journal of Small Business Management, Vol. 51, No. 1, pp 46-65.

Mundy, J. (2015). 'Where has strategy gone? Time to reclaim and rethink', Presentation at Sidrea International Workshop 'Management Control and Strategy. Theoretical and Empirical Evidence', University of Perugia.

Nanni, A.J., Dixon, J.R. and Vollmann, T.E. (1992) 'Integrated performance measurement: management accounting to support the new manufacturing realities', Journal of Management Accounting Research, Vol. 4 No. 1, pp. 1-19.

Naranjo-Gil, D. (2004) 'The role of Sophisticated Accounting System in Strategy Management', The international Journal of Digital Accounting Research, vol. 4, pp. $125-144$.

Neely, A.D. and Adams, C. (2000) 'Perspectives on Performance: The Performance Prism', Gee Publishing, London.

Neumüller N., Lasch R. and Kellner F. (2016) 'Integrating sustainability into strategic supplier portfolio selection', Management Decision, Vol. 54, No. 1, pp. 194-221.

Otley, D.T. (2001) 'Extending the boundaries of management accounting research: developing systems for performance management', British Accounting Review, Vol. 33, No. 3, pp. 243-261.

Parnell J.A., Long, Z. and Lester, D. (2015) 'Competitive strategy, capabilities and uncertainty in small and medium sized enterprises (SMEs) in China and the United States', Management Decision, Vol. 53, No. 2, pp. 402-431.

Patel P. C. and Cooper D. (2014) 'Structural Power Equality between Family and NonFamily TMT Members and the Performance of Family Firms', Academy of Management Journal, Vol. 57, No. 6, pp. 1135-1143.

Pindado J., and Requejo I. (2015) 'Family Business Performance from a Governance Perspective: A Review of Empirical Research', International Journal of Management Reviews, Vol. 17, No. 3, pp. 279-311.

Porter, M.E. (1990) The competitive advantage of nations, Free, New York.

Post C. and Byron K. (2015) 'Women on Boards and Firm Financial Performance: A Meta-Analysis', Academy of Management Journal, Vol. 58, No. 5, pp. 1459-1475.

Sage D., Dainty D. and Brookes B. (2013) 'Thinking the ontological politics of managerial and critical performativities: An examination of project failure', Scandinavian Journal of Management, Vol. 29, No. 3, pp. 282-291.

Shan, J. and Jolly, D.R., (2013) 'Technological innovation capabilities, product strategy, and firm performance: The electronics industry in China', Canadian Journal of Administrative Sciences/Revue Canadienne des Sciences de l'Administration, Vol. 30, No. 3, pp. 159-172.

Shank, J.K. (1989) 'Strategic cost management: new wine, or just new bottles?', Journal of Management Accounting Research, Vol. 1, No. 1, pp. 47-65.

Silchenko, K., Del Gobbo, R., Castellano N., Franceschetti, B.M., Tosi V. and La Verghetta M., (2015). 'Sorting Through Waste Management Literature: A Text Mining Approach to a Literature Review', in D. Gomezelj Omerzel; S. Laporšek, 'Managing Sustainable Growth', University of Primorska, Koper.

Simons, R. (1994). 'How top managers use control systems as levers of strategic renewal', Strategic Management Journal, vol. 15, pp. 169-189. 
Simons, R. (1995) 'Levers of control: how managers use innovative control systems to drive strategic renewal', Harvard Business School Press, Boston.

Steigenberger, N. (2014) 'Only a matter of chance? How firm performance measurement impacts study results', European Management Journal, Vol. 32, No. 1, pp. 46-65.

Su, W., and Tsang, E.W. (2015) 'Product Diversification and Financial Performance: The Moderating Role of Secondary Stakeholders', Academy of Management Journal, Vol. 58, No. 4, pp. 1128-1148.

Thaker, K. (2011) 'How does business performance measurement perform? An empirical study with reference to leading companies in India', International Journal of Business Performance Management, Vol. 12 No. 4, pp. 396-416.

Torres J. P., Drago C. and Aqueveque C. (2015) 'Knowledge inflows effects on middle managers' ambidexterity and performance', Management Decision, Vol. 53, No. 6, pp. 2303-2320.

Tseng K. A., Lan Y., Lu H. and Chen P. Y. (2013) 'Mediation of strategy on intellectual capital and performance', Management Decision, Vol. 51, No. 7, pp. 1488-1509.

Victer, R. (2014) 'The strategic implication of knowledge attributes: Understanding the conditions in which knowledge matters to performance', Management Decision, Vol. 52, No. 3, pp. 505-525.

Wang, Z., Wang, N. and Liang, H. (2014) 'Knowledge sharing, intellectual capital and firm performance', Management decision, Vol. 52, No. 2, pp. 230-258.

Wei, L.Q. and Wu, L. (2013) 'What a diverse top management team means: Testing an integrated model', Journal of Management Studies, Vol. 50, No. 3, pp. 389-412.

Whittaker, D.H., Fath, B.P. and Fiedler, A. (2016) 'Assembling capabilities for innovation: Evidence from New Zealand SMEs', International Small Business Journal, Vol. 34, No. 1, pp. 123-143.

Wu, J., Wang, C., Hong, J., Piperopoulos, P. and Zhuo, S,( 2016) 'Internationalization and innovation performance of emerging market enterprises: The role of host-country institutional development', Journal of World Business, Vol. 51, No. 2, pp. 251-263.

Xiao, S.S., Jeong, I., Moon, J.J., Chung, C.C. and Chung, J. (2013) 'Internationalization and performance of firms in China: Moderating effects of governance structure and the degree of centralized control', Journal of International Management, Vol. 19, No. 2, pp. $118-137$.

Xie, Z. and Li, J. (2015) 'Demand Heterogeneity, Learning Diversity and Innovation in an Emerging Economy', Journal of International Management, Vol. 21, No. 4, pp. 277-292.

$\mathrm{Xu}$ Y., Ribeiro-Soriano D. E. and Gonzalez-Garcia J. (2015) 'Crowdsourcing, innovation and firm performance', Management Decision, Vol. 53, No. 6, pp. 11581169.

Yadav, N., Sushil and Sagar, M. (2014) 'Revisiting performance measurement and management: Deriving linkages with strategic management theories', International Journal of Business Performance Management, Vol. 15, No. 2, pp. 87-105.

Zacca, R., Dayan, M. and Ahrens, T. (2015) 'Impact of network capability on small business performance', Management Decision, Vol. 53, No. 1, pp. 2-23.

Zhang, X., Zhong, W. and Makino, S. (2014) 'Customer involvement and service firm internationalization performance: An integrative framework', Journal of International Business Studies, Vol. 46, No. 3, pp. 355-380. 
A data-driven analysis of the current debate on the linkages between performance and strategy studies

Zhou L. and Wu A. (2014) 'Earliness of internationalization and performance outcomes: Exploring the moderating effects of venture age and international commitment', Journal Of World Business, Vol. 49, No. 1, pp. 132-142.

Zhou, Y., Hong, Y. and Liu, J. (2013) 'Internal commitment or external collaboration? The impact of human resource management systems on firm innovation and performance', Human Resource Management, Vol. 52, No. 2, pp. 263-288.

\section{Notes}

1. The authors are grateful to Roberto Del Gobbo (PhD - University of Macerata) for his precious support provided on the text mining analysis.

\section{Appendix 1 - List of Journals}

\begin{tabular}{|l|l|}
\hline 1) Academy of Management Journal & 21) International Journal of Project \\
2) Academy of Management Learning \& & Management 22) International Small \\
Education & Business Journal \\
3) Academy of Management Perspectives & 23) Journal of Economics \& Management \\
4) Academy of Management Review & Strategy \\
5) Accounting, Organizations and Society & 24) Journal of International Business \\
6) Advances in Strategic Management & Studies \\
7) Asia Pacific Journal of Management & 25) Journal of International Management \\
8) British Journal of Management & 26) Journal of Management Studies \\
9) Business \& Society & 27) Journal of Small Business \\
10) California Management Review & Management \\
11) Canadian Journal of Administrative & 28) Journal of Strategic Information \\
Sciences & Systems \\
12) European Journal of Operational & 29) Journal of World Business \\
Research & 30) Long Range Planning \\
13) European Management Journal & 31) Management Accounting Research \\
14) European Management Review & 32) Management Decision \\
15) Harvard Business Review & 33) Management Science \\
16) Human Performance & 34) Omega - International Journal of \\
17) Human Resource Management & Management \\
18) Human Resource Management Journal & 35) Organizational Behaviour and Human \\
(UK) 19) Human Resource Management & Decision Processes \\
Review & 36) Production Planning \& Control \\
20) International Journal of Management & 37) Scandinavian Journal of Management \\
Reviews & 38) Sloan Management Review MIT \\
\hline
\end{tabular}


Author

\section{Appendix 2 - Keywords occurrence frequencies}

\begin{tabular}{|c|c|c|c|c|c|}
\hline Keywords & Frequency & $\%$ & Keywords & Frequency & $\%$ \\
\hline $\begin{array}{l}\text { performance } \\
\text { management }\end{array}$ & 182 & 82,73 & team performance & 4 & 1,82 \\
\hline research & 101 & 45,91 & \#no_codes & 4 & 1,82 \\
\hline strategic management & 59 & 26,82 & cooperation & 3 & 1,36 \\
\hline firm performance & 53 & 24,09 & literature review & 3 & 1,36 \\
\hline organizational issues & 52 & 23,64 & management research & 3 & 1,36 \\
\hline knowledge & 35 & 15,91 & product diversification & 3 & 1,36 \\
\hline innovation & 34 & 15,45 & small business & 3 & 1,36 \\
\hline financial performance & 22 & 10,00 & subsidiary performance & 3 & 1,36 \\
\hline human capital & 16 & 7,27 & technological capability & 3 & 1,36 \\
\hline sustainability & 15 & 6,82 & analytic network process & 2 & 0,91 \\
\hline internationalization & 14 & \begin{tabular}{|l|}
6,36 \\
\end{tabular} & fdi & 2 & 0,91 \\
\hline competitive advantage & 13 & 5,91 & leadership & 2 & 0,91 \\
\hline $\begin{array}{l}\text { performance } \\
\text { measurement }\end{array}$ & 13 & 5,91 & outsourcing & 2 & 0,91 \\
\hline $\begin{array}{l}\text { management control } \\
\text { systems }\end{array}$ & 10 & 4,55 & pricing & 2 & 0,91 \\
\hline case study & 10 & 4,55 & taiwan & 2 & 0,91 \\
\hline china & 9 & 4,09 & task performance & 2 & 0,91 \\
\hline exploration & 8 & 3,64 & corporate culture & 1 & 0,45 \\
\hline social capital & 7 & 3,18 & corporate governance & 1 & 0,45 \\
\hline empirical research & 6 & 2,73 & $\begin{array}{l}\text { corporate social } \\
\text { responsibility }\end{array}$ & 1 & 0,45 \\
\hline entrepreneurship & 6 & 2,73 & creativity & 1 & 0,45 \\
\hline business model & 5 & 2,27 & experimental study & 1 & 0,45 \\
\hline company performance & 5 & 2,27 & emerging markets & 0 & 0,00 \\
\hline absorptive capacity & 4 & 1,82 & $\begin{array}{l}\text { family owned business } \\
\text { enterprises }\end{array}$ & 0 & 0,00 \\
\hline intellectual capital & 4 & 1,82 & resource based view & 0 & 0,00 \\
\hline productivity & 4 & \begin{tabular}{|l|}
1,82 \\
\end{tabular} & $\mathrm{~N}$ of Documents & 220 & \\
\hline stakeholders & 4 & \begin{tabular}{|l|}
1,82 \\
\end{tabular} & & & \\
\hline
\end{tabular}

